\title{
Evaluation in the Provinces and Territories: A Cross-Canada Snapshot and Call to Action
}

\author{
Robert E. Lahey \\ REL Solutions Inc. \\ Wayne MacDonald \\ Infinity Consulting and Legal Services \\ Krista Brower \\ Independent Evaluation Contractor \\ Kaireen Chaytor \\ Dalhousie University \\ Richard Hurstfield-Meyer \\ Ministry of Environment \\ Johann Jacob \\ Université Laval \\ Frankie Jordan \\ Ministry of Justice (retired) \\ Paul Kishchuk \\ Vector Research \\ Keiko Kuji-Shikatani \\ Ministry of Education \\ Linda E. Lee \\ Proactive Information Services Inc. \\ James C. McDavid \\ University of Victoria \\ Tess Miller \\ University of Prince Edward Island \\ Sahara Morin \\ Department of Finance, Yellowknife, NWT
}

Corresponding author: Robert E. Lahey, REL Solutions Inc., 305-150 Caroline Avenue,

Ottawa, ON, K1Y 4X8; relahey@rogers.com 
Abstract: Evidence-based decision-making and managing for results are terms often heard from politicians and senior government officials at both federal and provincial levels of government in Canada. But, while there is some level of understanding at the federal level in terms of the role and use of evaluation in measuring results, there is significantly less information readily available about the extent to which evaluation is being used at other levels of government. This paper provides a cross-Canada synopsis on the capacity and use of systematic evaluation at the provincial and territorial levels of government. Authors from nine provinces and two territories provide a succinct analysis of the extent to which evaluation is being used in their provincial/territorial government, as well as a description of the challenges and opportunities that lie ahead for evaluation. There is a paucity of published information on this subject, but the paper uses research conducted in 2001 as a benchmark to compare the state of affairs for evaluation within provincial/territorial governments. With limited progress over the past two decades, the paper offers an overview of findings and some proposed actions for the way ahead.

Keywords: evaluation use, government, public-sector evaluation

Résumé : La prise de décision fondée sur des preuves et la gestion axée sur les résultats sont des termes souvent employés par les politiciens et les hauts fonctionnaires, autant à l'échelon fédéral que provincial au Canada. Mais, quoiqu'il y ait un certain niveau de compréhension à l'échelon fédéral à l'égard du rôle et de l'utilisation de l'évaluation dans la mesure des résultats, la portée de l'utilisation de l'évaluation à d'autres échelons du gouvernement est moins bien connue. Cet article présente un résumé pancanadien de la capacité et de l'utilisation de l'évaluation à l'échelon provincial/territorial du gouvernement. Des auteurs de neuf provinces et de deux territoires offrent une analyse succincte de la mesure dans laquelle l'évaluation est utilisée au sein de leur gouvernement provincial/territorial, de même qu'une description des défis et des occasions d'amélioration liés à l'évaluation. Il y a peu de renseignements publiés sur le sujet, mais les auteurs ont utilisé des recherches effectuées en 2001 comme référence pour comparer la situation de l'évaluation au sein des gouvernements provinciaux/territoriaux. Le progrès noté ayant été limité au cours des deux dernières décennies, l'article propose un survol des résultats et certaines actions suggérées pour l'avenir.

Mots clés : utilisation de lévaluation, gouvernement, évaluation dans le secteur public

Despite the importance of government-delivered public services in Canada, there has been a dearth of research, analysis, and reporting on the systematic conduct and use of evaluation at the provincial level of government. The Canadian Journal of Program Evaluation (CJPE) devoted a special issue to provincial evaluation policy and practice in Canada two decades ago. Accounts of provincial evaluation activity were provided for Newfoundland and Labrador (Ross, 2001), Prince Edward Island (Mowry, Clough, MacDonald, Pranger, \& Griner, 2001), Quebec 
(Cabatoff, 2001), Ontario (Segsworth, 2001), Manitoba (Warrack, 2001), Alberta (Bradley, 2001), British Columbia (McDavid, 2001), and the Northwest Territories (Hicks, 2001).

There have since been fragmented discussions of evaluation in some provinces or regions (Gauthier et al., 2004, 2009), but little information, analysis, or understanding of the role and use of evaluation is available at the provincial/ territorial level of government. This was noted most recently in a 2018 study on the "evaluation industry" in Canada (Lahey, Elliott, \& Heath, 2018).

The importance of program and policy evaluation for any level of government, of course, is to equip program managers and senior decision-makers with detailed and objective information, analysis, and advice that will inform both management/learning and accountability in the design and delivery of government policies, programs, and services and the use of public funds. While evaluation is not a panacea, its use in government will increase the likelihood that optimal program and policy decision-making, and continuous improvement, represent the norm. (Auditor General of New Brunswick, 2004; Lahey, 2010; Treasury Board of Canada, 2016).

This research and practice note is the culmination of a set of individual enquiries across the provinces and territories conducted by an assembled group of evaluation practitioners. The study was undertaken over 2017 and 2018, and a standard set of 10 questions was employed by each researcher to investigate their provincial/territorial jurisdiction. Two broad themes were explored: an overview of the "current situation" regarding the capacity and use of evaluation, drawing on observations data and on interviews with senior government officials and internal evaluators; and an assessment of future evaluation challenges and opportunities ("looking ahead") for the use of provincial/territorial government evaluation. The latter is more subjective but does also draw upon feedback about expectations at that point in time. For journal purposes, each author's original paper has been stored in the Canadian Evaluation Society (CES) Grey Literature, and a link to each paper is given in this article.

The individual findings of each province and territory are reflected in the overview tables of this article. While they represent a snapshot taken in 2017-18, each provincial/territorial author has provided a 2019 perspective on the "looking ahead" element, with particular reference to what the findings might mean in terms of a "call to action" for gaining greater use of systematic evaluation in provincial governments.

As a pan-Canadian examination, even in its limited form, the paper offers a broad scan of the capacity and use of evaluation at the provincial/territorial level of government in Canada. Overview findings focus on the extent to which evaluation has been institutionalized across provinces/territories, the extent to which it is typically being used by this level of government, as well as challenges and future opportunities for evaluation within provinces/territories. Benchmarked against the 2001 findings noted above, this updated snapshot identifies a general lack of significant progress in the use of evaluation in the provinces/territories. It offers 
a set of potential "call to action" items for reflection by evaluators in general and the CES in particular.

\section{CURRENT STATE OF EVALUATION CAPACITY AND USE IN THE PROVINCES AND TERRITORIES}

Where evaluation "capacity" is really a function of issues of both supply and demand, this enquiry has focused largely on the demand side-the commitment and extent to which provincial public sectors are seeking and using evaluation information as part of their governance and management systems. In this context, commitment to evaluation is reflected in the institutional infrastructure that has been put in place to support the use of the function, the adequacy of resourcing, and the extent and nature of the evaluation work that gets carried out. The current state of evaluation in the provinces and two territories (we were not able to obtain information on Nunavut) is shown in Table 1 (institutional infrastructure) and Table 2 (extent of evaluation use by provincial/territorial governments).

\section{Institutional infrastructure for evaluation across provinces/territories}

Four key questions associated with institutional infrastructure for evaluation were asked by regional authors for their respective province and territory. The questions, along with the general conclusions drawn, are outlined in Table 3.

The detailed summary by province/territory is given in Table 1. Only two of the 10 provinces (Newfoundland \& Labrador [NL] and Quebec) had an evaluation policy in place within the provincial public sector, put in place in 2011 and 2014 respectively.

Not surprisingly, it is only Quebec and NL that have a "mandatory" requirement for evaluation, though the requirement actually results more in "planning" for evaluation than in its conduct, due to several barriers such as budgetary constraints and the availability of resources. Also, these same two provinces do have central direction that is intended to oversee evaluation being conducted within its provincial ministries. It should be noted that the Northwest Territories also has a central unit to oversee evaluation, when it gets carried out. And Ontario is suggesting that there are movements afoot to build mandatory evaluation at least into the policy-program planning process, and that central direction for evaluation is being developed.

With most provinces not having a specific evaluation policy, the nature of the demand for evaluation could and does vary quite substantially across provinces and even across ministries within any province where evaluation services are sought. It was noted that in many of the provinces there is generally not a "culture of evaluation," which is perhaps a function of the "limited understanding of the role of evaluation."

While the broad use of systematic evaluation in most of the provinces is generally low, we do see the use of the term "evaluation" in job titles, with dedicated evaluation units existing in some ministries in some provinces. Internal 


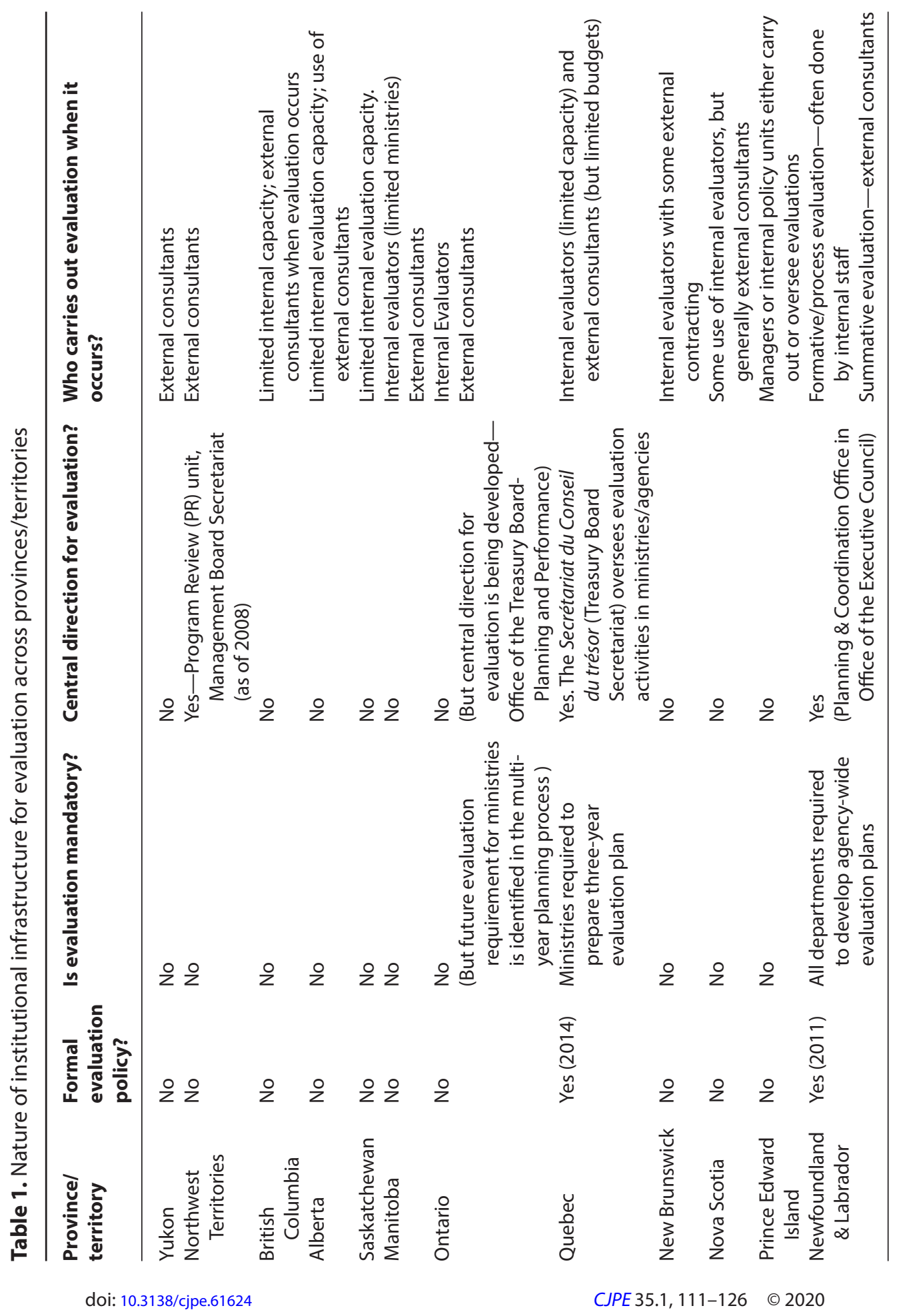


Table 2. Extent of evaluation use by provincial/territorial governments

\begin{tabular}{|c|c|c|c|}
\hline $\begin{array}{l}\text { Province/ } \\
\text { territory }\end{array}$ & $\begin{array}{l}\text { Evaluation } \\
\text { coverage ( } 100 \% \text { or } \\
\text { flexible?) }\end{array}$ & $\begin{array}{l}\text { Ministry adoption of } \\
\text { evaluation }\end{array}$ & $\begin{array}{l}\text { Nature/type } \\
\text { of evaluation } \\
\text { conducted }\end{array}$ \\
\hline Yukon & $\begin{array}{l}\text { Typically only } \\
\text { federal-territorial } \\
\text { contribution } \\
\text { agreements }\end{array}$ & $\begin{array}{l}\text { Education, Justice, } \\
\text { Health \& Social } \\
\text { Services }\end{array}$ & $\begin{array}{l}\text { When it occurs: } \\
\text { frameworks, } \\
\text { formative, and } \\
\text { summative }\end{array}$ \\
\hline $\begin{array}{l}\text { Northwest } \\
\text { Territories }\end{array}$ & $\begin{array}{l}\text { Targeted reviews } \\
\text { that address } \\
\text { program } \\
\text { effectiveness, } \\
\text { sustainability and } \\
\text { confirm mandate }\end{array}$ & $\begin{array}{l}2 \text { of } 11 \text { GNWT } \\
\text { departments } \\
\text { have dedicated } \\
\text { evaluation units }\end{array}$ & $\begin{array}{l}\text { Summative, } \\
\text { engagement } \\
\text { style to seek } \\
\text { Indigenous } \\
\text { government } \\
\text { perspectives }\end{array}$ \\
\hline $\begin{array}{l}\text { British } \\
\text { Columbia }\end{array}$ & $\begin{array}{l}\text { Flexible, with focus } \\
\text { on federal- } \\
\text { provincial } \\
\text { agreements }\end{array}$ & $\begin{array}{l}\text { Limited and uneven. } \\
\text { Ministry of Health has } \\
\text { largest focus on } \\
\text { evaluation }\end{array}$ & $\begin{array}{l}\text { When it occurs: } \\
\text { frameworks, } \\
\text { formative, and } \\
\text { summative }\end{array}$ \\
\hline Alberta & $\begin{array}{l}\text { Systematic } \\
\text { evaluation is } \\
\text { limited. Where it } \\
\text { exists, focus is on } \\
\text { specific programs } \\
\text { and pilots }\end{array}$ & $\begin{array}{l}\text { Evaluation units across } \\
\text { ministries uneven } \\
\text { in terms of capacity } \\
\text { and generally small }\end{array}$ & $\begin{array}{l}\text { General focus } \\
\text { on efficiency } \\
\text { and resource- } \\
\text { allocation issues }\end{array}$ \\
\hline Saskatchewan & Flexible & $\begin{array}{l}\text { Limited and uneven. } \\
\text { Systematic } \\
\text { evaluation exists } \\
\text { within a small } \\
\text { number of ministries }\end{array}$ & $\begin{array}{l}\text { "Evaluation" } \\
\text { equated to any } \\
\text { assessment } \\
\text { addressing } \\
\text { accountability, } \\
\text { processes, and } \\
\text { efficiency review }\end{array}$ \\
\hline Manitoba & $\begin{array}{l}\text { Systematic } \\
\text { evaluation } \\
\text { exists within a } \\
\text { small number of } \\
\text { ministries }\end{array}$ & $\begin{array}{l}\text { Very uneven across } \\
\text { departments. Strong } \\
\text { players: Healthy } \\
\text { Child Manitoba } \\
\text { (HCM); Indigenous } \\
\text { Inclusion } \\
\text { Directorate, } \\
\text { Manitoba } \\
\text { Education \& Training }\end{array}$ & $\begin{array}{l}\text { Focus of } \\
\text { government is } \\
\text { accountability, } \\
\text { value for money. } \\
\text { HCM evaluates } \\
\text { progress against } \\
\text { target outcomes }\end{array}$ \\
\hline Ontario & Flexible & $\begin{array}{l}\text { Most ministries have } \\
\text { evaluation units, } \\
\text { but very uneven in } \\
\text { terms of capacity } \\
\text { and maturity }\end{array}$ & $\begin{array}{l}\text { "Evaluation" } \\
\text { could include } \\
\text { summative, } \\
\text { formative, } \\
\text { developmental, } \\
\text { and evaluative } \\
\text { research }\end{array}$ \\
\hline
\end{tabular}




\begin{tabular}{|c|c|c|c|}
\hline $\begin{array}{l}\text { Province/ } \\
\text { territory }\end{array}$ & $\begin{array}{l}\text { Evaluation } \\
\text { coverage ( } 100 \% \text { or } \\
\text { flexible?) }\end{array}$ & $\begin{array}{l}\text { Ministry adoption of } \\
\text { evaluation }\end{array}$ & $\begin{array}{l}\text { Nature/type } \\
\text { of evaluation } \\
\text { conducted }\end{array}$ \\
\hline Quebec & $\begin{array}{l}\text { Evaluation } \\
\text { resources } \\
\text { cannot meet } \\
\text { the expanded } \\
\text { demands for } \\
\text { evaluation }\end{array}$ & $\begin{array}{l}\text { Demand for evaluation } \\
\text { has been created, } \\
\text { but resources (HR, } \\
\text { \$) are not there to } \\
\text { provide evaluation } \\
\text { services }\end{array}$ & $\begin{array}{l}\text { Summative and } \\
\text { effectiveness } \\
\text { evaluation to } \\
\text { support budget } \\
\text { decision- } \\
\text { making and } \\
\text { service } \\
\text { delivery }\end{array}$ \\
\hline New Brunswick & $\begin{array}{l}\text { Flexible-depends } \\
\text { on Ministry } \\
\text { deputy minister }\end{array}$ & $\begin{array}{l}\text { Very uneven- } \\
\text { secondary to other } \\
\text { performance } \\
\text { measurement tools }\end{array}$ & $\begin{array}{l}\text { Process studies; } \\
\text { focus on } \\
\text { efficiency before } \\
\text { effectiveness or } \\
\text { impact }\end{array}$ \\
\hline Nova Scotia & Flexible & $\begin{array}{l}\text { Uneven and generally } \\
\text { low }\end{array}$ & $\begin{array}{l}\text { When it occurs, } \\
\text { mostly formative }\end{array}$ \\
\hline $\begin{array}{l}\text { Prince Edward } \\
\text { Island }\end{array}$ & $\begin{array}{l}\text { Flexible, with focus } \\
\text { on federal- } \\
\text { provincial } \\
\text { agreements } \\
\text { (mandatory) }\end{array}$ & $\begin{array}{l}\text { Inconsistent and ad } \\
\text { hoc }\end{array}$ & $\begin{array}{l}\text { When it occurs, } \\
\text { could be } \\
\text { formative or } \\
\text { summative, } \\
\text { with } \\
\text { accountability } \\
\text { a key focus }\end{array}$ \\
\hline $\begin{array}{l}\text { Newfoundland } \\
\text { \& Labrador }\end{array}$ & $\begin{array}{l}100 \% \text { coverage not } \\
\text { required-risk- } \\
\text { based approach }\end{array}$ & $\begin{array}{l}\text { Of the } 12 \text { provincial } \\
\text { departments, } \\
\text { six have internal } \\
\text { evaluation } \\
\text { units }\end{array}$ & $\begin{array}{l}\text { Most common } \\
\text { are formative/ } \\
\text { process } \\
\text { evaluations }\end{array}$ \\
\hline
\end{tabular}

Table 3. Questions asked and conclusions drawn regarding institutional infrastructure

\begin{tabular}{|c|c|}
\hline Question & General conclusion \\
\hline $\begin{array}{l}\text { 1. Does the province/territory have a formalized } \\
\text { evaluation policy? }\end{array}$ & No \\
\hline $\begin{array}{l}\text { 2. Is the conduct of evaluation within the provincial/ } \\
\text { territorial government mandatory? }\end{array}$ & No \\
\hline $\begin{array}{l}\text { 3. Is there a body within the government that directs } \\
\text { and/or oversees the conduct of evaluation? }\end{array}$ & No \\
\hline $\begin{array}{l}\text { 4. Do provincial ministries carry out evaluation via } \\
\text { internal dedicated evaluation units, using external } \\
\text { evaluators, or some combination? }\end{array}$ & $\begin{array}{l}\text { Limited internal capacity; } \\
\text { often contracted externally }\end{array}$ \\
\hline
\end{tabular}


evaluation units, if they do exist within the provincial/territorial public sector, are typically located in ministries responsible for health, education, and social services. In most cases, evaluation that does get carried out by the ministry is contracted out to external evaluators, with internal evaluators playing a lesser role in general.

But even within the two provinces where an evaluation policy has been instituted, the original intent of broad evaluation coverage across most ministries has not occurred due to limited internal evaluation capacity and low budgets for the hiring of external consultants. Over time, the paucity of actual systematic evaluation has been exacerbated by budget cutbacks.

\section{Use of evaluation by provincial and territorial governments}

Detailed information on the extent of evaluation use by provincial/territorial governments is provided in Table 2 . This is based on the three key questions raised in the provincial/territorial enquiries, which are shown along with their general conclusions in Table 4.

The evidence suggests that evaluation in provinces/territories is generally either focused on programs that are federally funded (and require a formal evaluation as per the federal policy on transfer payments) or focused in areas of health, social services, and education. The latter generally differs from the formalized federal evaluation, often being either longer-term evaluative research or more performance measurement-oriented.

Apart from programs subject to federal-provincial agreements, demand for systematic evaluation by provincial/territorial governments has, with a few exceptions, to date been generally low, typically existing in a small number of ministries (health, education, and social services) which, as noted above, would likely have internal evaluation units. But, Ontario aside, there is a common theme that surfaces across the provinces and territories: limited evaluation capacity (in the form of internal evaluators or evaluation budgets), but no sense of an overall trend to build evaluation capacity.

With that said, evaluation would seem to be slowly evolving at the provincial/ territorial level; there has been some progress in the recognition of the value of

Table 4. Questions asked and conclusions drawn concerning extent of evaluation use

Question

General conclusion

6. Is there a requirement for $100 \%$ evaluation coverage, or is this flexible?

7. To what extent have ministries formally adopted evaluation in their operations?

8. What is the typical type/nature of evaluation that gets carried out?

Flexible

Limited and uneven

Formative; process; and efficiency 
evaluation and the adoption of evaluative approaches. As noted above, two provinces (NL and Quebec) have adopted evaluation policies, though insufficient resourcing of the function limits the amount of evaluation that actually gets carried out. Ontario for its part, though without a formal evaluation policy, in 2016 introduced into operational and central decision-making an "evaluation" standard for using evidence. But it is non-prescriptive, resulting in ambiguity about evaluation policy and practice in Ontario ministries. Some practitioners are concerned about a "lack of knowledge of what evaluation is and how it works", a general sentiment heard across the provinces back in 2001, and again nearly two decades later.

\section{Looking ahead: Challenges and future opportunities for evaluation in provinces/territories}

Table 6 provides regional details on what have been considered to be the key challenge(s) for evaluation, as well as future opportunities that may work in favour of evaluation in each province/territory (again with the exception of Nunavut; Newfoundland and Labrador did not submit a formal paper to the CES Grey Literature), based on responses to the questions asked and conclusions drawn that appear in Table 5.

A critical challenge for evaluation identified in all provinces and territories has been a lack of resources for carrying out evaluation, whether through internal evaluation units or the engagement of external evaluators on an as-needed basis. This is attributed in large part to a perceived lack of understanding among senior provincial/territorial officials of the role and utility of evaluation and an absence of an evaluation culture within ministries. It would seem that a higher priority is being given to internal audit or performance measurement-oriented tools/ approaches, where the former has a long-standing identity and the latter is, at least superficially, easier to establish and understand. But this is likely also a reflection of the provinces' preoccupation with financial management and accountability and not effectiveness and outcomes. In periods of fiscal constraint, particularly for the smaller provinces, this likely means that evaluation must compete for budgets, not only with program delivery but also with those tools or approaches that may be perceived as "substitutes" for evaluation. Such challenges for evaluation in the provinces have persisted throughout the first two decades of the twenty-first

Table 5. Questions asked and conclusions drawn concerning challenges and future opportunities

Question

9. Looking ahead, what are the key challenges faced for evaluation in the provincial/territorial government?

10. What are the future opportunities for evaluation?

\section{General conclusion}

Little evaluation awareness; low priority; limited capacity and resources

Some growing interest; small increases in capacity; potential partnerships 


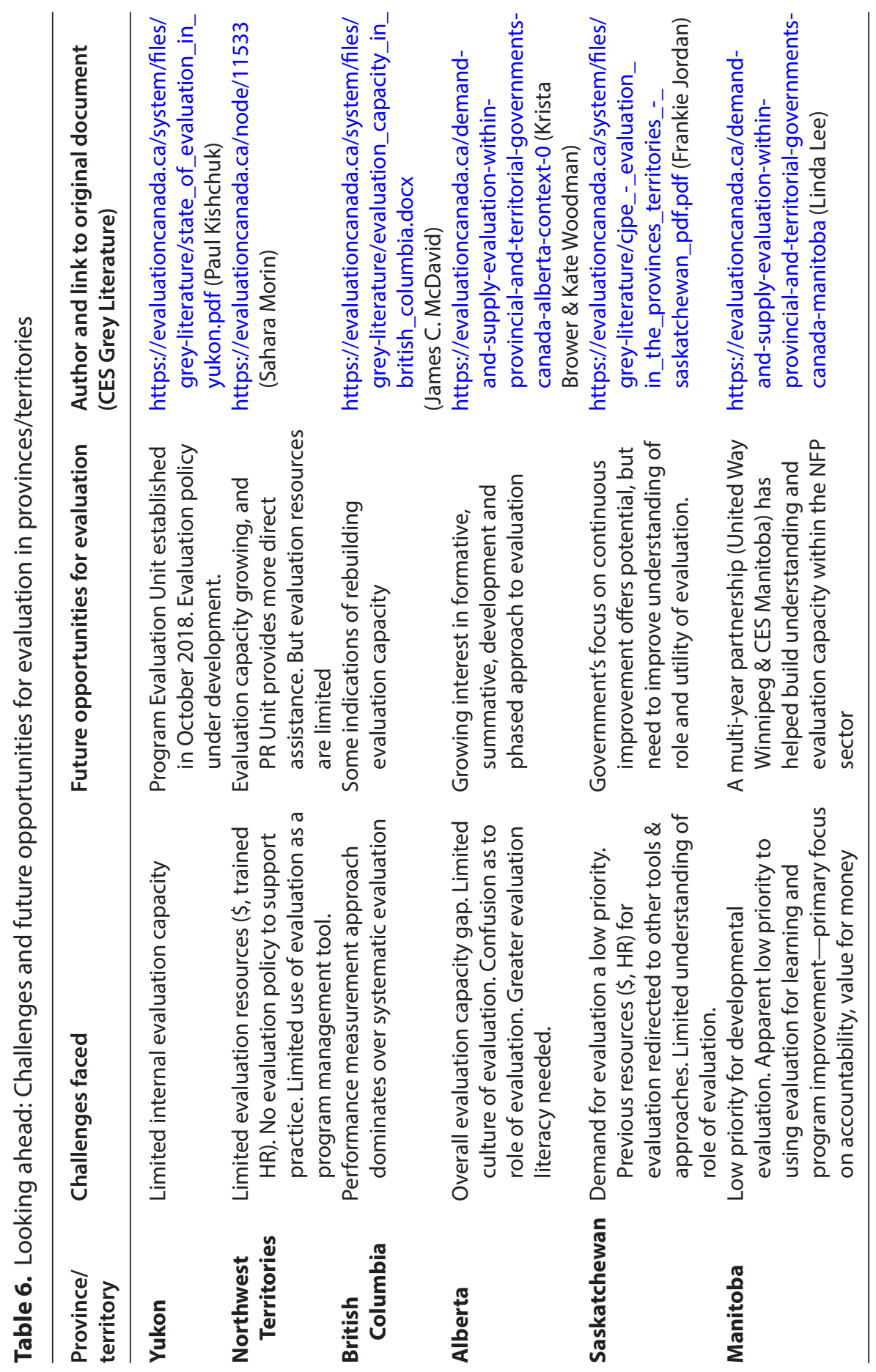




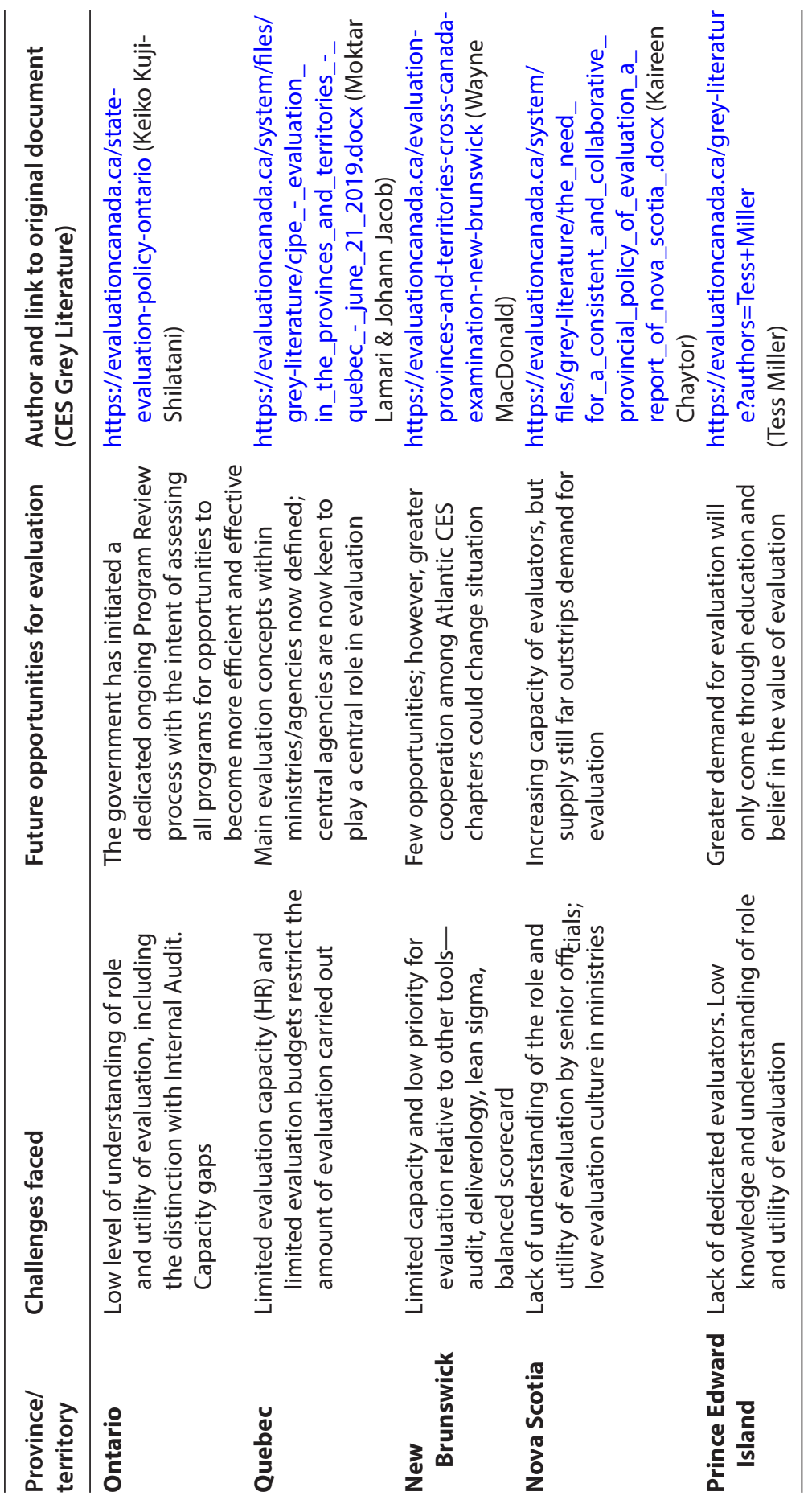


century (Auditor General of Alberta, 2005; Auditor General of New Brunswick, 2004; Seasons, 2001).

Future opportunities for evaluation would seem to look brighter for the larger provinces and the territories. The infrastructure in Quebec and the potential linking of evaluation to program review exercises in Ontario (along with planned building of evaluation infrastructure) offers some promise. Alberta, British Columbia, Manitoba, Saskatchewan, Yukon, and the Northwest Territories all offer some potential for future improvements in the state of evaluation use in their respective provincial/territorial government. The least promising would seem to be each of the Atlantic provinces, though Newfoundland and Labrador has indeed established a formal structure for evaluation. In all Canadian provinces and territories, though, there is an overriding concern about the lack of funding of evaluation. So what, if anything, can be done to rectify this situation?

\section{CONCLUSION: A "CALL TO ACTION" FOR EVALUATION IN PROVINCES AND TERRITORIES}

Our recent snapshot reveals that, for the most part, the provinces/territories have not yet embraced the concept of evaluation to the extent that they are adequately institutionalizing the function and funding of evaluation. Even where attempts have been made to put in place a more institutionalized mechanism for evaluation (Quebec and NL), insufficient support for internal evaluation and general budget cuts have limited its use and effectiveness.

There is enough evidence to suggest that this situation will not change in most provinces/territories unless there is a deliberate and proactive movement to address the need for change, so this article offers a set of proposed "call to action" items to be taken up by the Canadian evaluation community in general and the CES professional association in particular:

1. First, there is a need to recognize the challenges, particularly resourcing gaps, within the provincial/territorial evaluation sphere. This ought to be a priority area for the CES and built into the CES national long-term strategy, and CES Chapters, for action.

2. With no formal evaluation policy in most provinces/territories, evaluation could easily drop off the radar with a change in government, particularly where it has not been embedded as a key function of government. A long-term strategy is thus to encourage the introduction of an evaluation policy and associated standards into provincial/territorial public sectors.

3. However, equally important as the above is the need for an awarenessraising campaign and advocacy for the "value in evaluation" aimed at provincial/territorial political and senior administrative leadership. A coordinated effort by CES (both national and Chapters) needs to map out a communications strategy that gets integrated into the CES and 
Chapters' long-term strategy for action. In the Atlantic provinces, with smaller numbers, it might warrant a coordinated communication among Atlantic CES Chapters to wider regional audiences.

4. Building evaluation capacity on the demand side means identifying and targeting relevant audiences and occasions/fora for delivery, crafting messages in non-technical language that will resonate with key stakeholders who influence/drive the demand for evaluation, using various means and media to deliver messages, and being able to demonstrate in concrete ways the "value in evaluation." Audiences could include political leadership, ministry deputy ministers and senior officials, provincial Auditors General, universities, media, think tanks, policy fora, and public-sector audiences. They could be reached by a variety of written, electronic, or in-person mechanisms, including written or verbal briefings, formal presentations, webinars, opinion pieces, trade publications (e.g., Canadian Government Executive magazine), journal articles, oneon-one interviews/consultations, and so on.

5. Within the evaluation community, we need to become better communicators. It is an important competency, but we need to be able to better demonstrate specific instances of where and how evaluation has been beneficial to a program or organization. Part of this also is to investigate timely ways to get the message out about evaluation projects that have made a difference in government programming. From the field of professional journalism, evaluation could benefit from learning how to clarify its central "message" of its added value to citizens and the public discourse.

6. With provincial/territorial governments often tending to rely on mechanisms other than evaluation to gather "performance" information, we need to encourage academics and CES Fellows, among others, to write journal articles and academic papers that assess the adequacy of these "substitute" approaches within a broader evaluative framework, raising the issue of evaluation's comparative advantage and added value vis-à-vis other practices. These could be later drawn upon and/or repackaged as articles targeted to trade publications or other media.

7. Evaluators of course need to more closely examine why evaluation is not being embraced by provincial authorities_-including the long-standing complaint of government about the length of time it takes to get evaluation results. Some of this likely requires educating all sectors-including evaluators - of the wide range of tools and methodologies available in the field, along with the flexibilities that exist when addressing evaluation issues.

8. Finally, training and orientation may need to more clearly emphasize that the practice of evaluation is about making judgements to provoke conversations that will help bring change, when needed. Accordingly, in addition to the traditional concerns with evaluation methodology, train- 
ing may need to reinforce such topics as professional judgement, evaluation "conversations" and learning from evaluation, and how evaluation may support transformative development.

\section{REFERENCES}

Auditor General of Alberta. (2005). The challenges of evaluation in managing for results. Presentation to the Symposium on Accountability and Evaluation Systems in Complex Organizations, Edmonton, Alberta, February 24.

Auditor General of New Brunswick. (2004). Program evaluation in government departments. In Report of the Auditor General (pp. 120-143). Retrieved from https://www. agnb-vgnb.ca/content/dam/agnb-vgnb/pdf/Reports-Rapports/2004v2/agrepe.pdf

Bradley, S. E. (2001). Evaluation in the government of Alberta: Adapting to the "new way." Canadian Journal of Program Evaluation, 16(Special Issue), 29-44.

Cabatoff, K. (2001). The long march from evaluation to accreditation: Quebec's new "government management framework." Canadian Journal of Program Evaluation, 16(Special Issue), 73-88.

Gauthier, B., Barrington, G. V., Bozzo, S. L., Chaytor, K., Cullen, J., Lahey, R., . . Roy, S. (2004). The lay of the land: Evaluation practice in Canada Today. Canadian Journal of Program Evaluation, 19(1), 143-176.

Gauthier, B., Barrington, G. V., Bozzo, S. L., Chaytor, K., Dignard, A., Lahey, R., . . Roy, S. (2009). The lay of the land: Evaluation practice in Canada in 2009. Canadian Journal of Program Evaluation, 24(1), 1-49.

Hicks, K. (2001). Program evaluation in the government of the Northwest Territories, 1967-2000. Canadian Journal of Program Evaluation, 16(Special Issue), 107-114.

Lahey, R. (2010, November). The Canadian MઐE system: Lessons learned from 30 years of development. Evaluation Capacity Development Working Paper Series, No. 23. Washington, DC: World Bank.

Lahey, R., Elliott, C., \& Heath, S. (2018). The evolving market for systematic evaluation in Canada. New Directions for Evaluation, 160(Special Issue), 45-62. https://doi. org/10.1002/ev.20346

McDavid, J. C. (2001). Program evaluation in British Columbia in a time of transition: 1995-2000. Canadian Journal of Program Evaluation, 16(Special Issue), 3-28.

Mowry, S., Clough, K., MacDonald, B., Pranger, T., \& Griner, D. (2001). Evaluation policy and practice in the provincial government of Prince Edward Island. Canadian Journal of Program Evaluation, 16(Special Issue), 89-100.

Ross, A. (2001). Evaluation in Newfoundland: Then was then and now is now. Canadian Journal of Program Evaluation, 16(Special Issue), 101-106.

Seasons, M. (2001). Epilogue. Canadian Journal of Program Evaluation, 16(Special Issue), $115-118$.

Segsworth, R. (2001). Evaluation policy and practice in Ontario. Canadian Journal of Program Evaluation, 16(Special Issue), 59-72.

Treasury Board of Canada Secretariat. (2016). Policy on results. Ottawa, ON: Government of Canada. 
Warrack, B. (2001). Program evaluation in the Manitoba government: Past, present and future. Canadian Journal of Program Evaluation, 16(Special Issue), 49-58.

\section{AUTHOR INFORMATION}

Robert E. Lahey, founding head of Canada's Centre of Excellence for Evaluation, has led evaluation units in four federal departments/agencies. Since 2004, he has been advising Canadian/international organizations (including the World Bank, the UN, and countries globally) on evaluation. Internationally, as a keynote/international M\&E expert/"thought leader," he has recently been invited to speak at, among other venues, the 2017 Third Global Evaluation Forum (Kyrgyzstan) and the 2019 Helsinki Retreat on evaluating the SDGs. A CES Fellow, founding Credentialing Board member and 2004 "Contribution to Evaluation in Canada" Award recipient, Lahey serves on the UN Women's Advisory Committee on Oversight.

Wayne MacDonald is president of Infinity Consulting and Legal Services. He has held senior executive evaluation positions with SSHRC, CIDA, the Geneva-based ICRC, and UNICEF in New York. In 2010, Wayne co-edited the New Directions for Evaluation issue on "Enhancing Disaster and Emergency Preparedness Response and Recovery through Evaluation." He has a Master's degree in sociology from Carleton University (Ottawa) and a Certificate in Evaluation Practice (CEP) from The Evaluators' Institute (TEI) at Claremont Graduate University, California.

Krista Brower, a credentialed evaluator with over 12 years' experience, is Director of Evaluation \& QI for the Edmonton Oliver Primary Care Network and a member of the CES National and ABNWT Provincial Boards of Directors. Holding an M.Ed. in measurement, evaluation, and cognition, she is working toward her $\mathrm{PhD}$ in research, evaluation, and enhancement. Krista has extensive experience in the non-profit, health, and social services sectors.

Kaireen Chaytor is an adjunct professor in the School of Public Administration, Dalhousie University, and a Fellow of CES. She has conducted evaluations for more than 25 years and presented on several evaluation topics nationally and internationally. Kaireen has served on the CES National Board as well as the CES Educational Fund and Credentialing Board. Her interest now is using evaluation theory in education practice and evaluation capacity building.

Richard Hurstfield-Meyer is a practising Credentialed Evaluator (CE), Certified Change Management Practitioner (CCMP), and risk expert (CRM) with over 20 years of experience conducting evaluations and providing strategic advice in both the private and public sectors. Richard currently works for the Government of Ontario as a manager in a Program Metrics and Evaluation Unit.

Johann Jacob has over 10 years of experience in program evaluation. He is a $\mathrm{PhD}$ candidate at Université Laval in the Faculty of Education. His research pertains to climate-change adaptation and the adoption of pro-environmental behaviors in Quebec municipalities. $\mathrm{He}$ is also a lecturer in program evaluation at ENAP. Johann has to his credit two books, as well as some fifty scientific articles and evaluative research reports.

Frankie Jordan has conducted program evaluations in education and justice, in collaborative projects and with community-based organizations for over twenty years. She has been extensively involved in program development and implementation. She has also guided strategic and organizational planning, program review, and Lean initiatives in government. 
Frankie has held executive positions on the Saskatchewan Chapter and with CES National, including President of CES National from 2006 to 2008. She received the CES Service to the Society Award in 2010.

Paul Kishchuk is a public finance economist and Credentialed Evaluator. Paul has completed more than 250 research and evaluation assignments for a diverse array of privateand public-sector clients through Vector Research, the independent economic research consultancy he founded in Whitehorse in 1999. Paul applies a place-based lens to all his Yukon evaluation assignments. Paul is president of the Yukon Chapter of CES.

Keiko Kuji-Shikatani is grounded as an internal evaluator with the Ontario Ministry of Education. She infuses evaluative thinking in collaborative teams to build sector capacity for the use of evidence to inform decisions and practice applying developmental evaluation principles. An expert on evaluator competencies and professionalization, she was instrumental in the development and operationalization of the CES CE designation, which has been documented in CJPE for the use of VOPEs around the world.

Linda E. Lee has worked in evaluation and research for 40 years. She has been a keynote speaker, presented papers, and facilitated workshops at many national and international conferences. She has worked across Canada and internationally. Linda, a former CES National President, received the 2003 Service to CES Award and was inducted as a Fellow in 2009. She serves on the CES Credentialing Board and on the Fellows' Executive.

James C. McDavid is professor emeritus in the School of Public Administration at the University of Victoria. He has conducted research and program evaluations focusing on federal, state, provincial, and local governments in the United States and Canada. His recent published research focuses on teaching evaluation and the prospects for professionalizing the field. The third edition of his textbook, Program Evaluation and Performance Measurement: An Introduction to Practice was published by Sage Publications in 2019.

Tess Miller is a credentialed evaluator and associate professor at the University of Prince Edward Island. Her work is situated in quantitative methodologies and spans university, provincial, and federal jurisdictions. She conducts essential skills workshops in PEI and is currently involved in a needs assessment for workplace learning, PEI. She is a long-standing board member of the PEI Chapter of the CES.

Sahara Morin began her career in evaluation and performance measurement with the Government of the Northwest Territories in 2004. From 2004 to 2017, Sahara held progressively senior roles in central agency departments responsible for government-wide guidance, support, and oversight in the areas of program research, analysis, evaluation, and business planning. Sahara has been a vocal advocate for evidence-based decision making, for which a corporate culture of periodic evaluation and ongoing program monitoring is critical. 